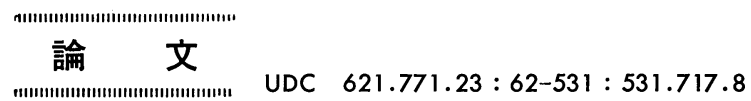

\title{
厚板平面形状認識装置と最適スラブ設計解析システム
}

\author{
萩原 康彦* . 久保多貞夫*。八柳 博*.川畑 友明*
}

\section{Instrument for Detecting Plate Shape and System for Analyzing Optimum Slab Size for Plate}

Yasuhiko Hagrwara, Sadao Kubota, Hiroshi Yatsuyanagi, and Tomoaki Kawabata

Synopsis:

For the improvement of plate product yield, a new unique system which contains high level technology for sizing and cutting plates and appropriate slab size design has been developed. The characteristic features of the system are as follows:

(1) PSG (Plate Shape Gauge) has been developed and can measure a plate upon completion of rolling and provide that data to the computer accurately indicating the plate's top view profile.

(2) The automation of optimum sizing, optimum cutting and inspection of plate has been realized using the recognized plate pattern image along with finishing data for the plate.

(3) The system for analyzing optimum slab size for plate with various data such as data obtained by PSG has been developed.

This system has been carried out at the plate mill in Wakayama Steel Works since 1977 and has brought about the improvement of product yield of $2.2 \%$ as a direct effect plus substantial labor savings.

\section{1. 緒}

厚板压延における歩留りを向上させる主な方法とし $\tau$,

（1）板厚・板幅の圧延寸法精度（邓らい精度拉よび 変動) の向上1)2

(2) 圧延材平面形状の矩形化 ${ }^{3)}$

（3）採寸・切断の高精度化とスラブ設計の適正化 が考兄られる。（1）については油圧圧下装置や厚及計お よび計算機システムの発達により大きく向上してきた. また $(2)$ そついて子近年エッジャの積極的活用や压延中 に板厚を制御する方法によつて平面形状を矩形化する 技術が急速に向上してきている。しかるに(3)について の研究はほとんど見られない，著者らは压延まま材の全 平面形状を正確に認識し適切な切断を行うこと沶よびそ の認識データをスラブ設計などに反映させることにより 大幅な圧延歩留りの向上が可能であることに注目し，圧 延まま材の全平面形状の認識方法と認識データの有効な 利用技術についての検討を行つて，厚板平面形状認識装 置 (Plate Shape Gauge; PSG と呼ぶ) とスラブ設計を
解析するためのシステム（両者を合わせて本システムと 呼ぶ）を開発した．直接的な効果だけでも $2 \%$ を越兄る 歩留り向上を実現している，本報では開発経過とその機 能について述べる.

\section{2. 歩留りロスの分析}

厚板の注文歩留りは合格製品重量と使用スラブ重量の 比で与えられる. 著者らは 1973 年〜1974 年に歩留り口 スの分析を行い，Fig. 1 に示す結果を得た.この結果は 変動余裕に関するロスが全体の $36 \%$ を占め，歩留り口 スを減少させるための重要な対象であることを示してい る. 更に詳細に分析した結果，適切でない採寸拉よび切 断によつて発生するロスや，スラブ設計が適切でないた めに生じる口スの比率が非常に高いことが判明した，そ こで压延ままの厚板全平面形状を高精度に測定し，その データと成品寸法を用いて自動採寸および切断を指示す る装置と，その認識情報を活用してスラブ設計の適正化 を図るための解析システムの開発を行らことにした.

Table 1 飞歩留り口スの特性要因と本システムの期待効 果の関係を示す。

昭和 55 年 10 月本会講演大会にて発表 昭和 56 年 3 月 20 日受付 (Received Mar. 20, 1981)

* 住友金属工業(株)和歌山製鉄所 (Wakayama Steel Works, Sumitomo Metal Industries, Ltd., 1850 Minato Wakayama 641) 
Table 1. Relationship between this system and yield loss.

\begin{tabular}{l|l|c|c}
\hline \multicolumn{1}{c|}{ Description of loss } & Classification \\
\hline Crop loss & (1) End crop loss (2) Side crop loss & (A) \\
\hline & $\begin{array}{l}\text { (1) Plate layout loss } \\
\text { (2) Allowance for intermediate cutting with crop-shear }\end{array}$ & A \\
\cline { 2 - 4 } $\begin{array}{l}\text { Allowance } \\
\text { loss }\end{array}$ & $\begin{array}{l}\text { (3) Surplus losses caused by the difference between actual and planned } \\
\text { allowance and between requested and actual slab weight }\end{array}$ & B \\
\cline { 2 - 4 } & (4) Loss due to inaccuracy of thickness (5) Others & - \\
\hline Production planning surplus & (B) \\
\hline Rejection loss & A \\
\hline
\end{tabular}

[Note] Classification A ; PSG is directly effective. Classification B; Analysis sysem is directly effective. ( ) means indirect effect.

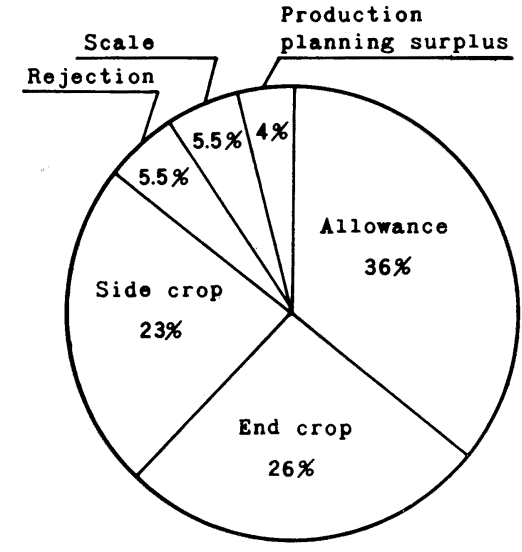

Fig. 1. Conventional yield losses.

\section{PSG の 開 発}

\section{1 目的}

圧延したままの厚板は細かく見るとフィッシュテー ル，圧延キャンバー，たいこ形状などが重なり合つて複 雑な平面形状を呈している。また厚板は通常複数の注文 品を取り合わせて压延され精整ラインにおいて成品寸法 飞切断され成品となるが，従来は採寸作業を始めとする 精整作業を人間の目視確認によつて手動で行つていた. これを自動化することと，認識した平面形状情報を有効 活用することがその目的であり大別すると次のようにな る.
（1）厚板平面形状の全自動迅速測定
(2) 採寸関連処理の全自動化
（3）採寸以降の精整工程での平面形状情報の活用
(4) 圧延へのフィード・バック
(5) 最適スラブ設計へのフィード・バック

\section{$3 \cdot 2$ 測定対象}

圧延したままの厚板材が対象であり寸法範围は

\section{板厚 $\quad 4.5 \mathrm{~mm} \sim 75 \mathrm{~mm}$}

板幅 $\quad 1000 \sim 4300 \mathrm{~mm}$

板長さ $6000 \sim 40000 \mathrm{~mm}$ である.

\section{3 基礎検討}

最大板幅 $4300 \mathrm{~mm}$, 压延長さ $40000 \mathrm{~mm}$ の2次元寸 法を持つ厚板の全平面形状を高精度に測定・認識できる ようにするため基礎検討を行い以下の結果を得た.

\section{$3 \cdot 3 \cdot 1$ 測定場所の選択}

長尺材の全平面形状測定を一度に高精度に行うことが 困難なため，通板中に順次測定する方法を考皇なければ ならない，この場合通板中の鋼板の上下運動や横振れお よび回転運動の存在は測定方法を複雑にすると共に測定 精度を悪化させる.そのため切削用バイトを使つたテス 卜機を作成し，搬送中の鋼板表面に羁書き線を入れ横振 れや回転の特性を調查して次の結果を得た.

（1）搬送中鋼板の一時停止や逆転は横振孔や回転を 発生させる.

（2）压延中鋼板やレベリング中鋼板は回転運動を伴 5 .

（3）搬送テーブルローラの偏摩耗が大きくなくかつ 鋼板が低速 $(1 \mathrm{~m} / \mathrm{s}$ 程度) 一定速度で搬送される場合は 横振れや回転は無視できる.

以上の結果と使用目的を考慮して冷却床出側の表裏面 検查場を測定場所とした.

\section{$3 \cdot 3 \cdot 2$ 厚板先後端平面形状特性}

厚板の平面形状の中でも先後端形状が特に複雑であり 測定方法を決定する大きな要素となるため, 写真撮影法 による形状特性調查を行い次のような結果を得た。

（1）先後端形状は大別すると凸型対称形状 - 凹型対 称形状·非対称形状の 3 つに分類されるが，対称形状の 
ものについては両側ェッジ共板長さ方向に $45^{\circ}$ 以上の傾 きを持つ部分のクロップ長さはほぼ $100 \mathrm{~mm}$ 以内のもの が大部分であり，端部の凹凸形状のためほとんど成品と はできない。また，それより長いクロップ長を持つ場合 はその板幅は成品幅より小さいと考えてよい.

（2）非対称形状のものも， $45^{\circ}$ 以上の傾きを持つ部 分はその板幅が成品幅より小さいと考えても実用上問題 ない。

\section{4 測定方法と測定機器}

(1) 測定方法

本装置はテーブルローラ上を搬送される鋼板の通過長 さと，その位置に拈ける鋼板両エッジ幅方向位置をコン ピュータに読み取り, 長さ方向 $(\mathrm{X})$ と幅方向 $(\mathrm{Y})$ の 座標を使つて鋼板平面形状のイメージをコンピュータ内 に認識させるものであり，幅計・測長計・凹型クロップ 測定装置・光幕式検出器などの測定機器とコンピュータ によつて構成されている. Fig. 2 にその測定機器構成 をまた Photo. 1 に測定中の本装置の写真を示す.

次に各測定機器に対して配慮した点について述べる.

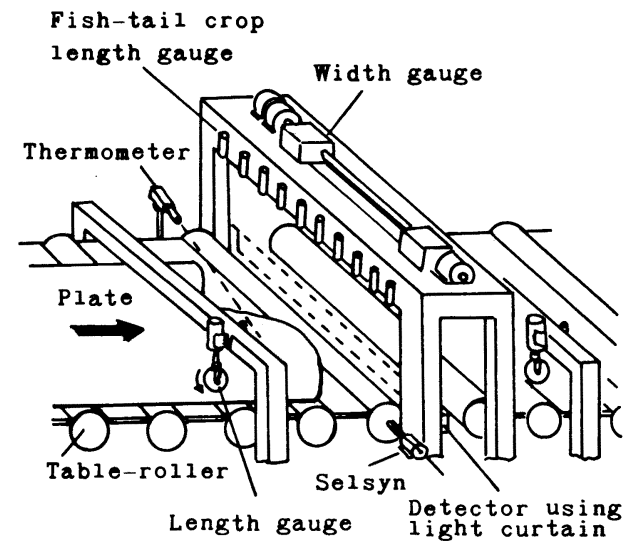

Fig. 2. Composition of PSG.
(2) 幅計

PSG に用いる幅計は

(1) 最大幅 $4300 \mathrm{~mm}$ で幅変動の大きな鋼板を高精度 に測定できること.

(2) 応答速度が速いこと.

が要求されるため 4 本の螢光灯を組み合わせた下部光源 を用いた下部光源方式のディジタル化された幅計を採用 している.この方式では測定原理上視野内で板幅が変化 しても一つの代表板幅が測定されるが，視野内で板幅が 大きく変化する場合は測定精度が悪くなる．この問題に は可能な限り鋼板進行方向の視野幅を狭くする方法で対 処した. Table 2 に板幅变動のある被測定材の板幅測定 精度と幅計測定視野七ンターからの被測定材エッジの偏 りに対する板幅測定精度を示す. 表において $\alpha$ の值が大 きくなる程精度は悪化するが，3.2.2 で前述したように $\alpha \leq 45^{\circ}$ の測定が重要であることを考虑すると実用上十 分な精度と言える。

(3) 測長計

PSG はさまざまな形状を持つ鋼板先後端の通過を正 しく認識し，鋼板全長にわたる長さ方向位置を高精度に 測定する必要がある.このため Fig. 3 に示すよらに, 点や線ではなく光の幕を利用した検出器により面で検出 して鋼板先後端の凹凸形状やそりに対しても正確に測定 できるようにした。 またタッチローラ式測長計を幅計の 前後に 2 台設置し組み合わせて使らことにより鋼板全長 各点の測長精度を高くしている. Fig. 4 とその測定精 度を示す。

\section{(4) 凹型クロップ測定装置}

上述した幅計の測定視野から外れる鋼板幅方向中心部 を光電管を多数用いた装置で測定し凹型クロップ形状特 性を求める.

\section{5 認識パターン上での採寸}

Fig. 5 は板幅 $2300 \mathrm{~mm}$ の成品を 3 枚取り合わせた

Table 2. Measuring error of width gauge.

(Error $=$ Measuring value-Actual value)

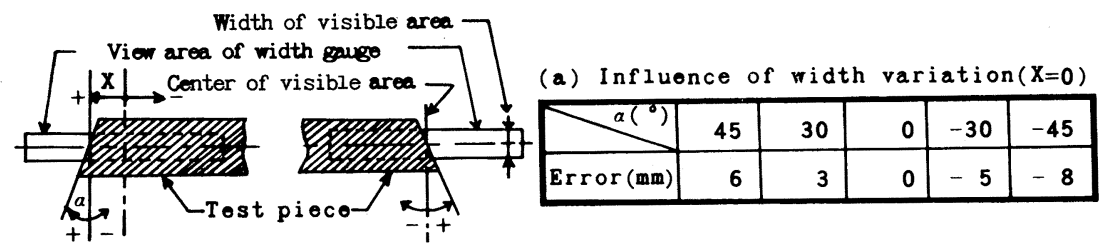

(b) Influence of deviation $\left(a=0^{\circ}\right)$

\begin{tabular}{|r|r|r|r|r|r|r|r|r|r|}
\hline$X(m \mathbf{m})$ & 200 & 150 & 100 & 50 & 0 & -50 & -100 & -150 & -200 \\
\hline Error (m) & 1 & -1 & 0 & 0 & 0 & 1 & 1 & 0 & 1 \\
\hline
\end{tabular}


圧延長さ約 $38 \mathrm{~m}$, 成品厚 $11.0 \mathrm{~mm}$ の圧延まま材を $\mathrm{PSG}$ で測定・認識した鋼板イメージ上に，精整指示情報に基 ついて切断仮想線を描いた認識結果の例である。また压 延キャンバー量や最大幅, 最小幅など平面形状特性值の 測定結果も合わせて示す。シャーラインでの幅切断は長 さ切断前に行うため，図のように压延キャンバーが大き い時矢のままでは切断できず，クロップシャーによる中 間切断(中切と呼ぶ)指示が必要となる。また成品採取後 に残つた余剩部分についてはその長さを求めている.

さて Fig. 6 はクロップ部分を少なくかつ無理のない

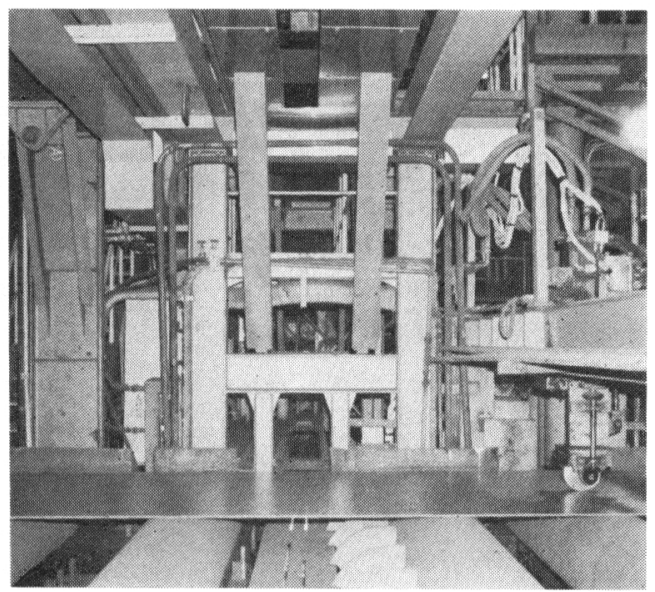

Photo. 1. PSG

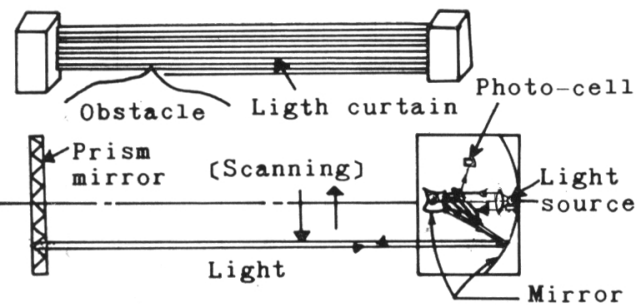

Fig. 3. Principle of the detector using light curtain.
幅切断ができる先後端切断位置の決定方法の説明図であ る.図に招いて，Aは幅切断に必要な板幅 $W_{\text {MiN }}$ が確 保でき始める位置であり，B は板幅変動が無視し得る位 置（すなわち板幅方向両エッジの $|d Y / d X| \leq 一$ 定值を 満足し始める位置）とする. $W_{\mathrm{MiN}}$ はシャ一切断の場合 次式となる。

$W_{\mathrm{MiN}}=W_{\mathrm{A}}+\Delta W_{\mathrm{AMS}}+C \times\left(\Delta W_{\mathrm{APL}}-\Delta W_{\mathrm{AMS}}\right)$

$+\Delta W_{\mathrm{C}}+\Delta W_{\mathrm{CS}}$

ただし， $W_{\mathrm{A}}$ : 成品幅 $(\mathrm{mm}) \Delta W_{\mathrm{APL}}$ : 幅上限公差 $(\mathrm{mm})$ $\Delta W_{\mathrm{AMS}}$ ：幅下限公差 $(\mathrm{mm}) \quad C$ : 定数 $(-)$ $\Delta W_{\mathrm{C}}$ : 切断代 $(\mathrm{mm}) \Delta W_{\mathrm{CS}}$ : 切断余裕代 $(\mathrm{mm})$ ここで, 切断余裕代とは認識䛊差执よび鋼板エッジの折 れ込久および疵を考慮した值である。また図中の $d$ は そ B の幅中心の幅方向距離を示寸，切断位置は， $d \geq d_{\mathbf{0}}$ (=一定值) の場合 $d=d_{\mathbf{0}}$ となる $\mathrm{A}^{\prime}$ の位置，また $d \leq$ $d_{0}$ の場合 $\mathrm{A}$ の位置とする.

Fig. 7は中切位置と中切量を決定寸る方法の説明図で ある。ここでは説明を簡単にするため 2 成品取り合わせ の場合を考古る．認識した鋼板パターン上で切断仮想線 をどのように置き換えても中切なしでは幅切断ができ ず，図に示すように中切が必要となる。中切量は幅切断 仮想線の傾きにより幾何学的に決定する。 3 枚以上の成

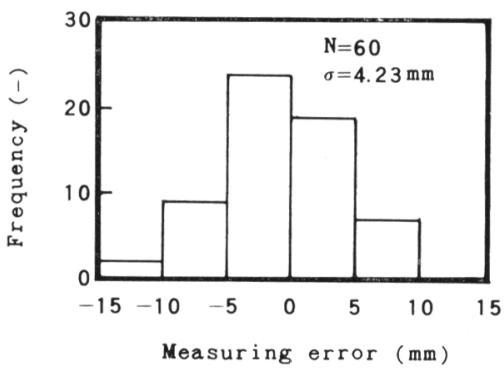

Fig. 4. Measuring error of length gauge. (Measuring range : Under $26 \mathrm{~m}$ )

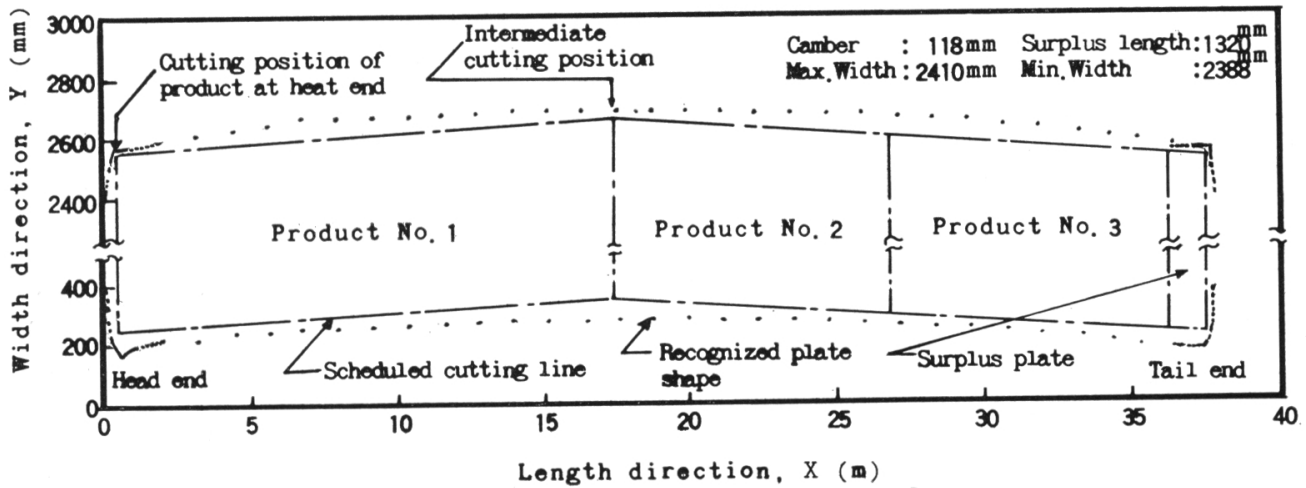

Fig. 5. Recognition of plate's shape by PSG. 


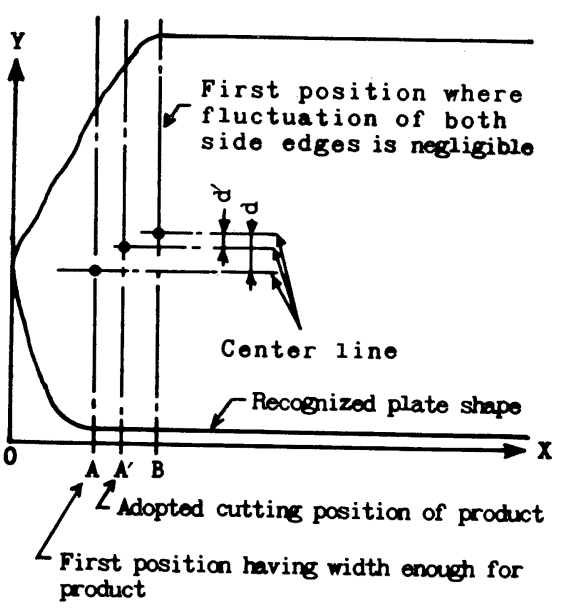

Fig. 6. Method for decision of cutting position at plate ends.

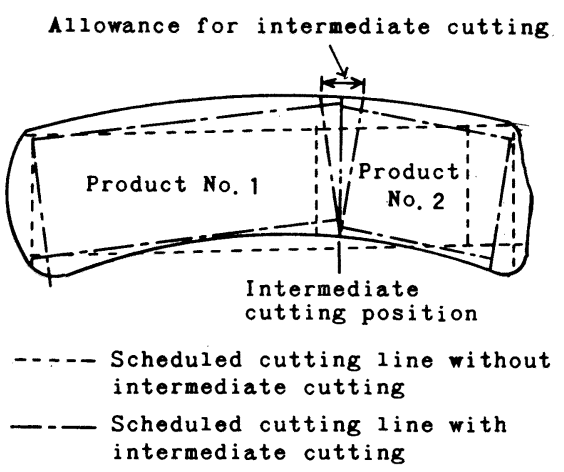

Fig. 7. Method for deciding intermediate cutting position and allowance of intermediate cutting.

品取り合わせの場合は 2 回まで中切ができる。 また幅切 断なしで出荷する厚板 (耳付材と呼ぶ) の板幅検査も上 述の採寸機能の拡張（すなわち切断仮想線を耳付成品の 必要最小成品エッジ仮想線に置き替えること）によつて 自動的に行える.

\subsection{PSG の精度}

PSG の総合精度は全鋼板エッジの2次元寸法がどの程 度正確に認識されているかを求めることによつて得られ る. この際問題となる真の值の求め方については, テス ト材として 5 枚の専用材を用意しガス切断法により任意 の平面形状を人工的に作成してその寸法をオフラインで 正確に計測する方法をとつた. 測定結果の一例を Fig. 8 に示す．再現性を含めた測定精度は良好であるといえ る. また後端側については先端側の結果に前述の測定精 度を加えた程度の測定結果となつている。

\subsection{PSG 認識結果の活用方法}

PSG 関連システムの機器構成と認識結果の活用方法
概要を Fig. 9 に示す.このシステムは図に示すように 前述の測定機器， 1 台のミニコン，1台のプロコン，1 台の生産管理用計算機で構成されている. 主な活用方法 は次のと拈りである.

(1) ステンシルの全自動化

採寸結果を用いてステンシル装置に印刷タイミングを 自動設定することにより切断前鋼板に対するステンシル 作業の全自動化をはかつている.

(2) 郝書きの全自動化

自走式の台車を持つチョーク方式の自動羁書き装置に 対して必要な郝書き位置を自動設定する.

(3) 自動切断

採寸計算結果を利用して厚板の先端から後端までの切 断指令をディバィドシャーに与えることにより全長自動 切断化をはからている.

(4) 耳付材板幅検査の自動化

前述のように成品採取可否の確認を行い，不可の場合 は検査場に拈いて再検查の指示をする。

(5) ミル・オペレータへのフィード・バック

板幅過不足・压延キャンバー・板長過不足をミル・オ ペレータヘフィード・バックする.

(6) スラブ設計解析システムへのフィード・バック

(7) 自主管理活動での解析

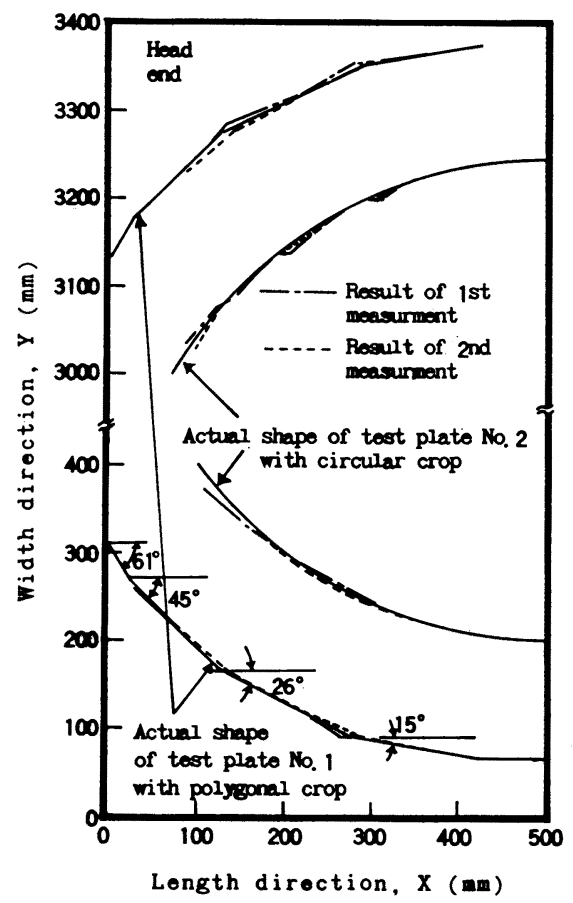

Fig. 8. Examples of results measured by PSG with test plates. 


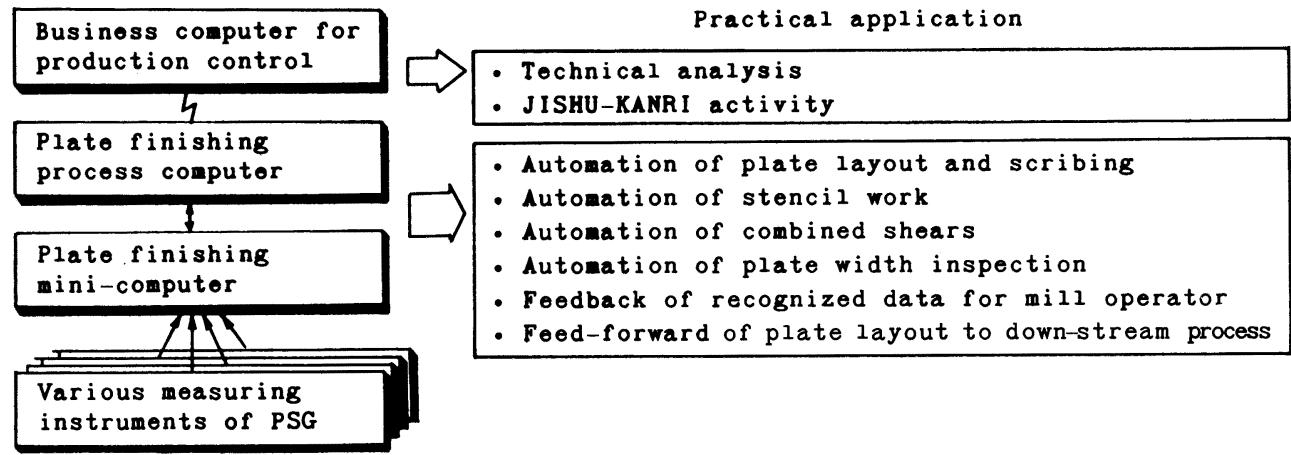

Fig. 9. Diagram of the plate shape recognition and related equipment.

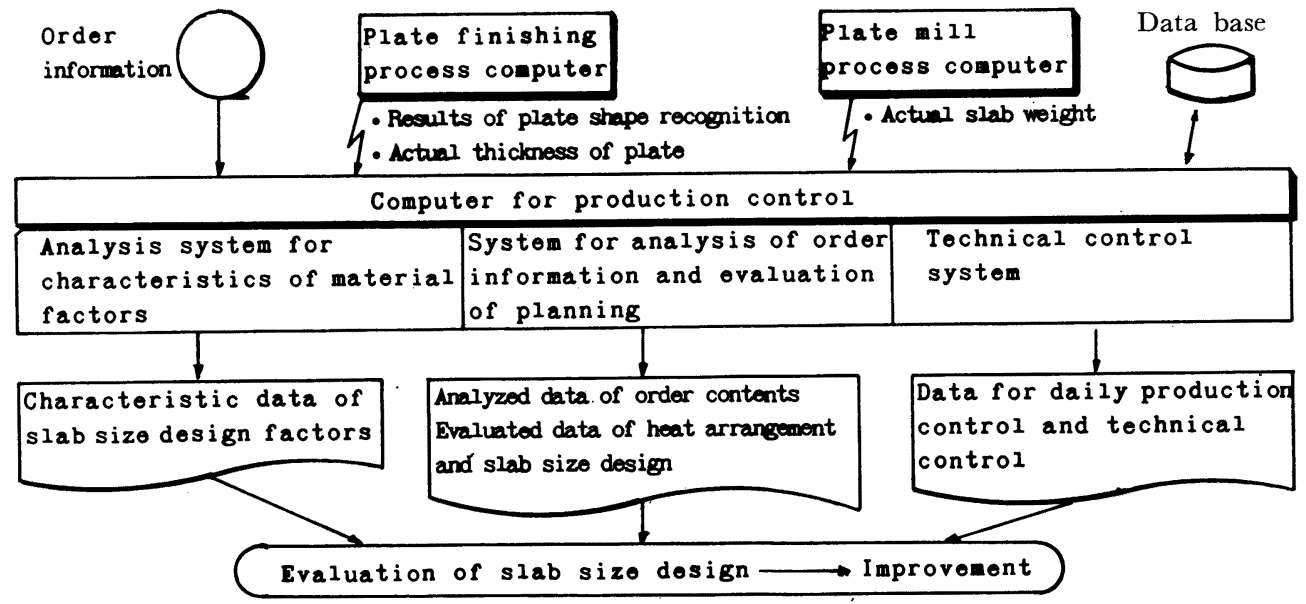

Fig. 10. Schematic of analysis system for slab size design.

\section{4. スラブ設計適正化のための解析システム}

\section{1 従来の問題点}

厚板の製造においてスラブ設計の良否は歩留りおよび 能率にきわめて大きな影響を与えるが

（1） スラブ設計に考虑すべき要因の数が多いこと.

（2）それら諸要因，特に平面形状データを定量的に 大量に求めることが困難なこと.

（3）諸要因の特性が複雑なため計算機による解析計 算が必要なこと.

などの問題点があつた．そこで諸要因となる情報を正 確にかつ大量に収集し特性分析が容易に行える Fig. 10 に示すようなシステムを開発した。

\section{2 厚板の素材スラブ設計}

スラブ設計の適正化とは，圧延における寸法ばらつき や平面形状の変動を考虑して，受注した成品を採取でき る範囲で最小限のスラブ寸法を決めることである，素材 であるスラブの請求重量 $G(\mathrm{~g})$ は次式で与えられる.

$$
\begin{aligned}
& G=\{\rho /(\alpha \cdot \beta)\} \times(h+\Delta h) \times(w+\Delta w) \times(l+\Delta l) \\
& \rho: \text { 材料の密度 }\left(\mathrm{g} / \mathrm{mm}^{3}\right) \quad 1-\alpha: \text { スラブ手入ロス }(-) \\
& 1-\beta: \text { スケールロス }(-) h: \text { 板厚 }(\mathrm{mm}) \\
& w: \text { 板幅 }(\mathrm{mm}) \quad l: \text { 成品合計長 }(\mathrm{mm}) \\
& \Delta h: \text { 板厚変動余裕 }(\mathrm{mm}) \quad \Delta w: \text { 板幅変動余裕 }(\mathrm{mm}) \\
& \Delta l: \text { 圧延長余裕 }(\mathrm{mm}) \\
& \text { ここで } \alpha, \beta, h, \Delta h, w, \Delta w, l, \Delta l \text { は成品寸法. 公差. }
\end{aligned}
$$

製造仕様・素材寸法によつて決定される变数である.

\section{3 解析方法}

(1) 因子

各圧延材に対してそれぞれの PSG 認識情報（クロッ プ長, キャンバー量, 発生余剰長, 板幅など), 板厚実 績, スラブ関連情報, 成品情報などを生産管理用コンピ ュータのデータ・ベースに蓄える.

(2) 分析の方法

その時の圧延技術の水準（すなわち圧延寸法精度）や 素材スラブの製造技術水準（すなわち請求に対する実績 スラブ 寸法精度) に適したスラブ 請求寸法を求めるた 


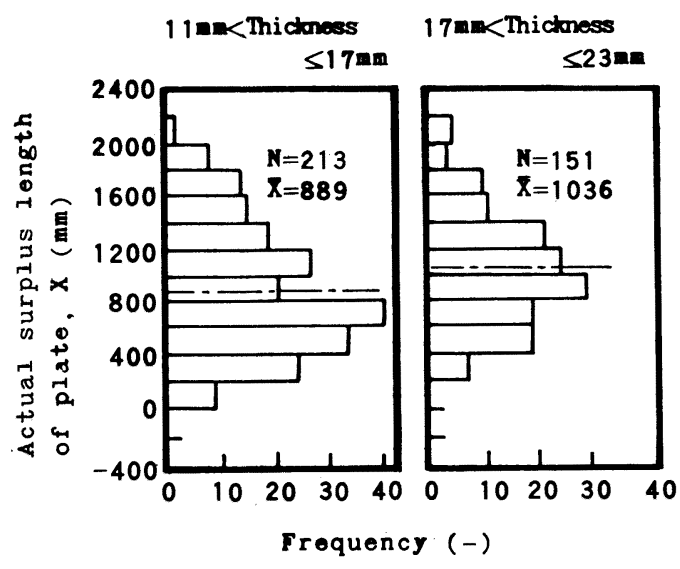

Fig. 11. Examples of relation between plate thickness and actual surplus length.

め, 発生余剩長を計算する. Fig. 11 は発生余剩長の一 定板厚範囲毎のヒストグラムの例を表したものである. 板厚が $17 \mathrm{~mm}$ から $23 \mathrm{~mm}$ の対象材は全体に $200 \mathrm{~mm}$ 板長相当分の スラブ 請求重量が過剩であることがわか る. 更にその他の圧延条件, たと光ば板厚と板幅とを組

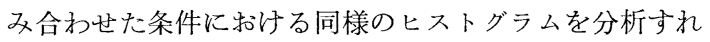
ば別の過剩分が明らかになる，クロップ長，板厚，板ク ラウン，板幅，板長さ，請求に対するスラブ重量偏差な ぞ精度特性についても合わせて分析し過剩分の多い対象 についてその理由を詳細に解析できる。 またスラブ手入 グレードと実績クロップ長の関係を求め, スラブ設計式 の $\Delta l$ をスラブ手入グレードの関数にすることもできる.

(3) 評価方法

分析で得られた結果に従つてスラブ設計式を補正す る.これらの補正が適切かどらかは, 計画内容評価シス テムを使ってスラブ・チャージ・日・弾位の計画注文 歩留りを求めて評価すると共に, 日常技術管理システム を使つて日々の寸法不良発生状況の把握と原因の分析を 行う.

\section{5. 効果}

寸法不良，特に長さ不良之注文歩留りは深い関係があ る. 寸法不良は確率的発生特性を持つているため，不良 率=0をねらう場合には相当な余裕代をスラブ設計上付 加する必要があり歩留りが低下する．従つて注文納期上 問題がでない範囲で寸法不良と注文歩留りをバランスさ せたスラブ設計が求められる. Fig. 12 亿和歌山製鉄所厚 板工場飞批注文歩留りの向上代と寸法不良率の推移 を示す. 5 年間で約 $4 \%$ の歩留り向上を果たしてきたが そのうち $2.2 \%$ は本システムの直接効果によるものであ

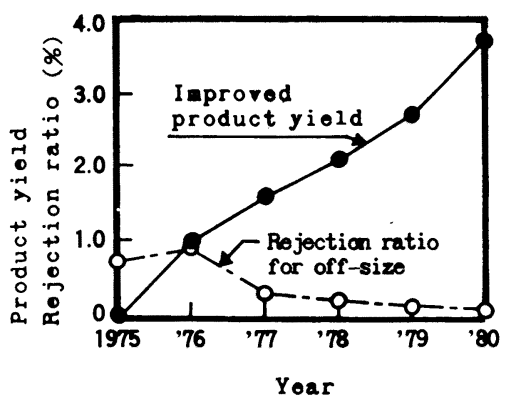

Fig. 12. Improvement of product yield and rejection ratio for off-size.

1976 : Completion of PSG

1977 : Completion of analysis system for material design

1978 : Improvement of analysis system

る。またこの間寸法不良率も減少しているが，このこと は本システムによる改善が合理的に行われていることを 意味している。この他に省力にも大きな成果をあげた。

\section{6. 結言}

厚鋼板の全平面形状を認識し高精度な採寸拉よび切断 が自動的に行えると共にその認識データを用いて適正な スラブ設計条件を求めることのできるシステムを研究開 発して，和歌山製鉄所厚板工場で以下の成果を得た.

（1）搬送中の圧延まま鋼板の全平面形状を高精度に 測定する方法を開発した。

（2）測定した鋼板の全平面形状パターン上での適正 な採寸計算方法を開発した.

（3）採寸計算によつて求めた結果を用いて羁書き・ ステンシル・切断・板幅検査の自動化を実現した.

（4）鋼板の平面形状認識データなど各種データをデ 一タ・ベース化し，特性分析が容易にできるスラブ設計 解析システムを開発し，歩留りロスの大きな要素である 変動余裕を合理的飞削減した.

最後に本システムの開発は多数の方々の指導と協力に よつて実現できたことを付記する。

\section{交献}

1 ) 岡本豊彦, 美坂佳助, 横井玉雄, 木瀬一孝, 藤巻 镢：住友金属，27(1975) 3, p. 74

2 ) 久保多貞夫，八柳 博：住友金属，30 (1978) 4, p. 102

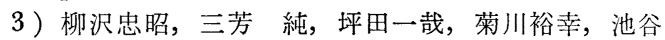
尚弘, 磯山 茂, 旭 一郎, 馬場和史：川崎製鉄 技報， 11 (1979) 2，p. 1 